\title{
Materials and Tools across Volcanoes: Exploitation of Georesources in Piano dei Cardoni (Ustica, Italy) during Prehistory
}

\author{
Claudia Speciale*,1,2 Giuseppe Montana $^{3}$, Roberta Mentesana ${ }^{4}$, Vincenza Forgia ${ }^{5}$, \\ Filippo Mantia ${ }^{5}$, Giuseppina Battaglia ${ }^{6}$, Mauro Antonio Di Vito ${ }^{1}$, Stefano Vassallo ${ }^{6}$, \\ Sandro de Vita ${ }^{1}$
}

\author{
(1) Istituto Nazionale di Geofisica e Vulcanologia, Osservatorio Vesuviano, Naples, Italy \\ (2) Department of Historical studies, University of Gothenburg, Sweden \\ (3) Dipartimento di Scienze della Terra e del Mare, Università di Palermo, Italy \\ (4) ARQUB, Departamento d'Història i Arqueologia Universitat de Barcelona, Spain \\ (5) Dipartimento Culture e Società, Università di Palermo, Italy \\ (6) Soprintendenza Beni Culturali e Ambientali di Palermo, Italy
}

Article history: received May 15, 2021; accepted October 29, 2021

\begin{abstract}
The paper aims at merging the first results from the analyses of the georesources exploited in the site of Piano dei Cardoni (Ustica island, Italy) during the Neolithic phases of its occupation (MiddleLate Neolithic, 4.7-4.2 ka cal BC). Grinding tools consist of a very varied typology of local volcanic rocks, easy to collect and available very close to the investigated site. A selection of shapes and lithology is applied to reach the best performance of the tools. The elevated number of grinders, pestles, mortars testify to an intense activity of food/plant processing in the site. The absence of chert or obsidian resources on the island pushed the human communities to import such raw materials from the Aeolian islands and probably from the north-western area of Palermo. Pumice is collected on the same island, probably due to the local availability and its good quality. Similarly, local clay resources are used for the manufacture of ceramics, mostly burnished and incised wares. Ustica was therefore almost autonomous for the exploitation of resources, with volcanic rocks readily available in abundance and with the most significant exception being chert and obsidian. This last one probably imported and worked on the island and then moved towards North-Western Sicily.
\end{abstract}

Keywords: Neolithic; Chert; Obsidian; Ceramics; Volcanic tools.

\section{Introduction}

In the definition of the cultural landscape, whatever the declination is, two factors are always present: human and environment and how they interact [Sauer, 1925; Mercuri et al., 2010; Mercuri, 2014; Clement and Cassino, 2018; Plieninger and Bieling, 2009]. Technical choices made in the manufacturing sequence, especially of ceramic 


\section{Claudia Speciale et al.}

production, but also for lithic assemblages, are not only about the technology itself, but they also represent cultural choices, social concerns and the record of connection routes [Lemonnier, 1993; Mentesana and Fragnoli, 2020; Dobres, 2009; Clarkson, 2008; Horowitz and McCall, 2019]. In particular, in volcanic areas, the dialogue between past communities and the local environment should be read through the interpretation of the geological dynamics [Di Vito et al., 2009; Di Renzoni et al., 2016; Riede et al., 2020]. Volcanoes present not only hazards but also a unique opportunity for georesource exploitation. For example, the role that lava querns and millstones play from the onset of agriculture until recent times is well known all over the Mediterranean and beyond [Santi et al., 2015; Renzulli et al., 2019; Kadowaki, 2021], sometimes from great distances already during prehistory [Bracchitta 2015]. Furthermore, during the Middle/Late Neolithic (6th-5th millennium BCE) in the Central Mediterranean, during a phase of growing contacts and consolidated exchange of goods, obsidian played a primary role in the establishment of short- and long-distance networks [Martinelli et al., 2019]. As a further example, soils composed of volcanic ash can have an important influence on agricultural production [Neall, 2006]. Volcanic islands are even more complex and intriguing for the analysis of cultural landscapes, because of their limited resources [McLaughlin et al., 2018; Fitzhugh et al., 2016], the possible discontinuity in the human occupation [Dawson, 2014; Horsburgh et al., 2017; Di Napoli et al., 2020] and also the capacity to develop very specific cultural landscapes [Rackham, 2012; Walter and Hamilton, 2014].

The case study analysed here is the small volcanic island of Ustica. Despite being quite remote from the Sicilian coast, the perception of its marginality might have changed throughout prehistory, according to the exchange dynamics and the cultural contacts of the Southern Tyrrhenian [Fitzpatrick et al., 2016]. This paper aims at merging the first results from the analysis of the archaeological materials of the site of Piano dei Cardoni (Ustica, Italy) during its phases of Neolithic occupation (4.7-4.2 ka BCE). After the typological classification of the artefacts (lithic tools and ceramics), the georesources and their uses are analysed: raw material identification and provenance are tackled via analyses of micro-and macro-components of pumice, obsidian, lava stones and ceramics, in order to explore the exploitation of Ustica's insular landscape and the potential network of contacts with other regions.

\section{Geological and archaeological context}

The investigated area is located in the north-eastern part of Piano dei Cardoni at Ustica, which is a flat land representing a marine terrace. It is connected to the Ustica central relief by a talus deposit. This erosional surface is related to a transgressive-regressive cycle of Crotonian age (isotopic stage 9; $350 \mathrm{ka} \mathrm{BP}$ [Shackleton and Opdyke, 1973], set on older submarine and subaerial lavas [de Vita et al., 1993; 1998].

During its formation, the abrasion surface of the terrace was the site of marine sedimentation that formed a detrital blanket composed of fossiliferous carbonate concretions and silt, sands and gravels due to the reworking of pre-existing volcanic rocks at the foot of the sea-cliff that borders the terrace. Afterwards the terrace was tectonically displaced from its original position and the detrital blanket continued its evolution in a subaerial environment, with the formation of talus breccias and a thick paleosol that also includes large rounded boulders, formed by in situ spheroidal weathering of lava [de Vita, 1993]. The Piano dei Cardoni lowland occupies an ENE-WSW trending land-strip, more-or-less parallel to the central ridge of the island, which ranges between 80 and $120 \mathrm{~m}$ of elevation a.s.l., with a 5\% mean slope. Moreover, the terrace slightly dips eastward, due to tectonic displacement. The excavated site is situated above and within the uppermost strata of the detrital blanket [Speciale et al., 2021a].

Ustica is the emerged part of a large extinct Pleistocene volcano, which rises more than 2,000 $\mathrm{m}$ above the Southern Tyrrhenian Sea floor [Barberi et al., 1969; Barberi and Innocenti, 1980]. The island is located $60 \mathrm{~km}$ north of the Sicily coast and about $100 \mathrm{~km}$ west of the Aeolian islands (Figure 1). It occupies an area of less than $9 \mathrm{~km}^{2}$ and reaches a maximum elevation of $248 \mathrm{~m}$ a.s.l. with Mt. Guardia dei Turchi in the E-W elongated ridge of hills, located in the central part of the island.

Ustica is predominantly composed of volcanic rocks, with only subordinate marine and continental sedimentary deposits. Volcanic rocks were produced by both subaqueous and subaerial effusive and explosive eruptions [Romano and Sturiale, 1971; Cinque et al., 1988; de Vita, 1993; de Vita et al., 1995; 1998; de Vita and Foresta Martin, 2017]. Marine sedimentary rocks consist of clayey sands, organogenic and detrital fossiliferous limestones, and carbonate concretions. They were sedimented during Middle-Upper Pleistocene sea level high-stands, related to glacio-eustatic movements, which also generated five orders of marine terraces [de Vita and Orsi, 1994]. Carbonate speleothems, 


\section{Exploitation Georesources in Piano dei Cardoni}

landslide deposits, loose detrital fans and aprons, sometimes pedogenized, are deposits of continental origin, related to the more recent geomorphological evolution of the island [de Vita, 1993]. Volcanism was active since the lower/middle Pleistocene until the last eruption, which occurred at 130 ka BP [Romano and Sturiale, 1971; Cinque et al., 1988; de Vita, 1993; de Vita et al. 1995; 1998; de Vita and Foresta Martin, 2017]. Therefore, it is reasonable to assume that humans had to interact only with the exogenous morphodynamic processes, active on the island in more recent times [Speciale et al., 2019] (Figure 2).

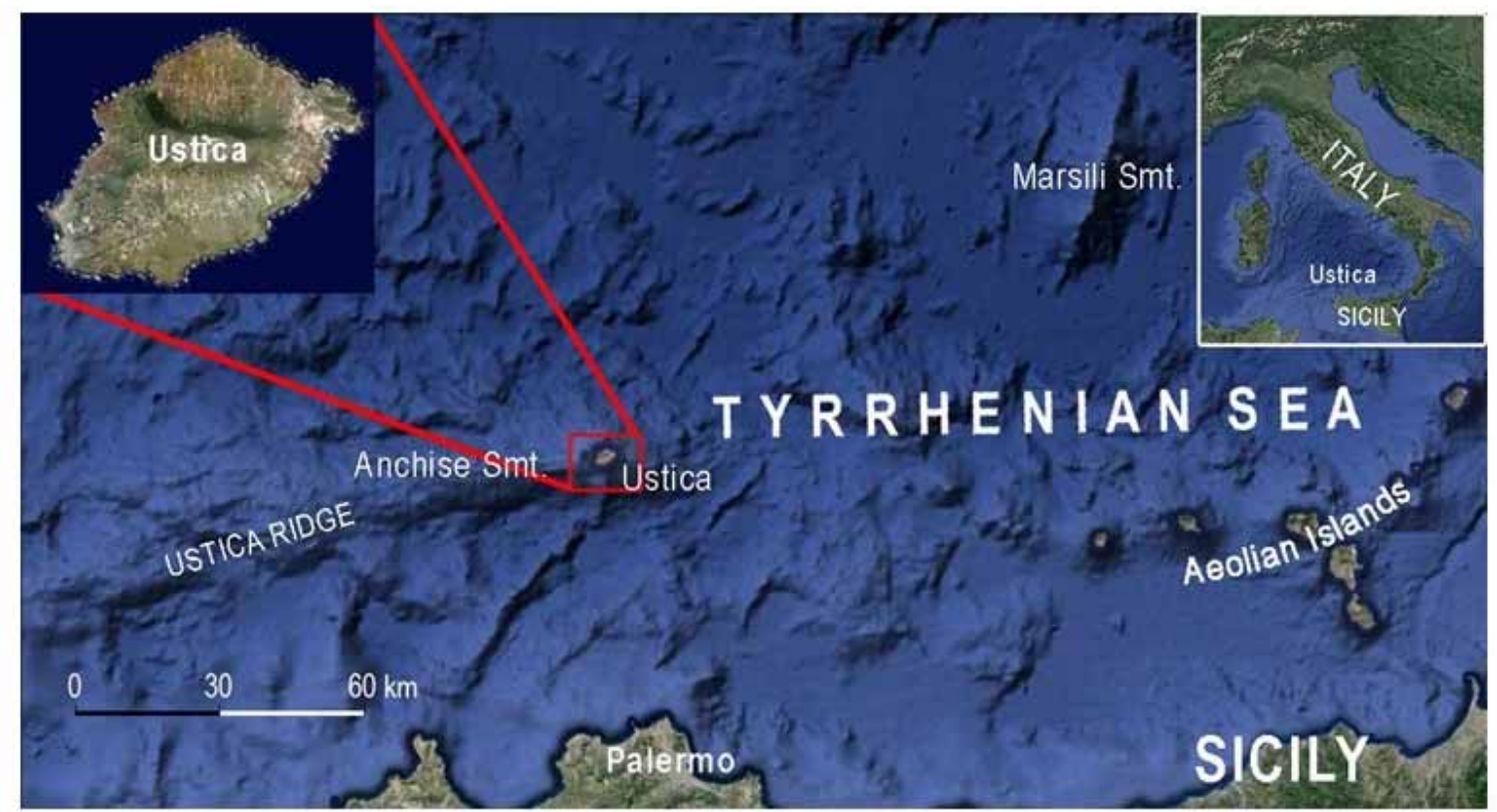

Figure 1. Position of Ustica in the Thyrrenian sea (modified after Google Earth; Image Landsat, Data SIO, NOOA, US Navy, NGA, GEBCO, Map Data (c) 2016).

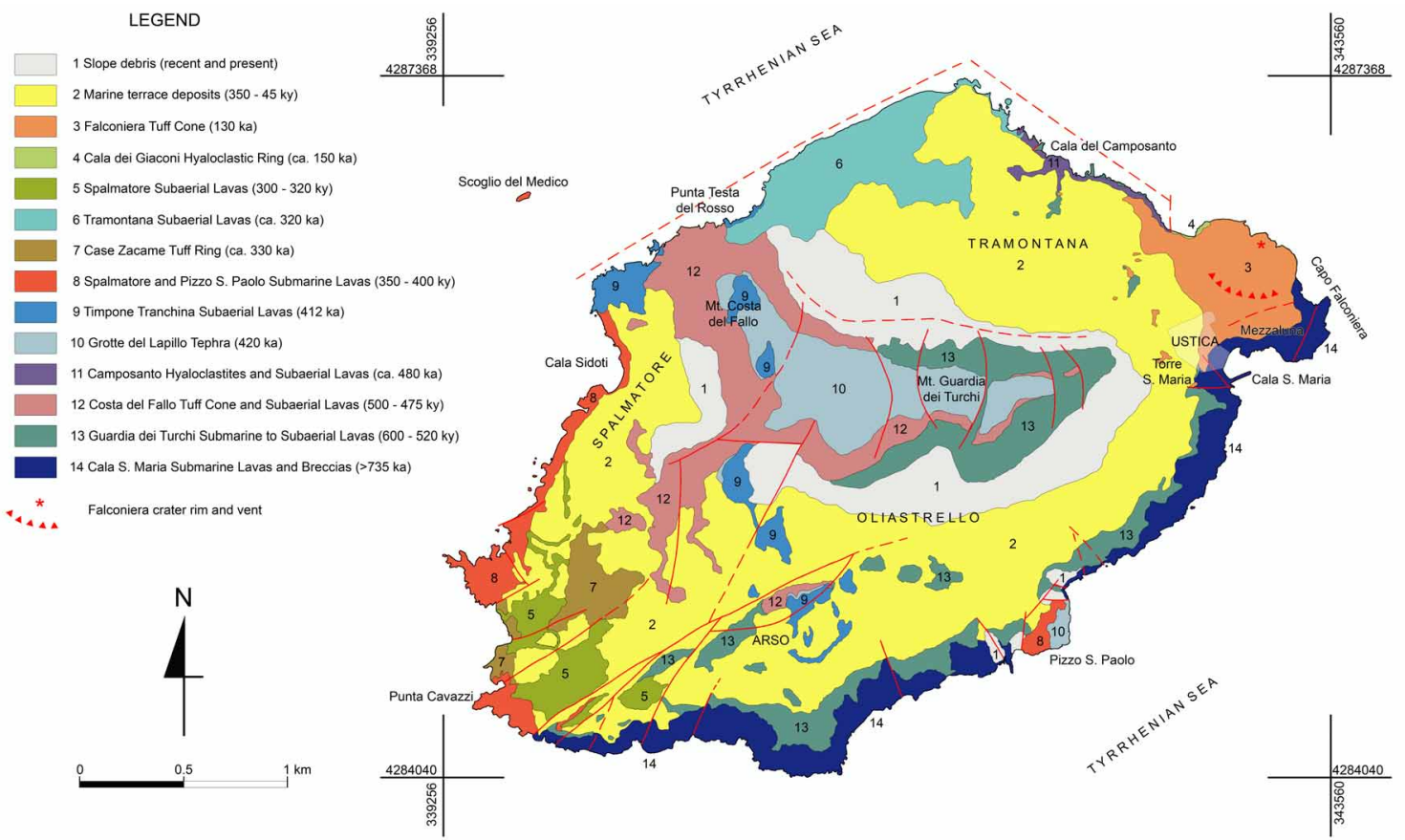

Figure 2. Geological map of the island with the position and age of all the formations [de Vita and Foresta Martin, 2017]. 


\section{Claudia Speciale et al.}

Ustica has been occupied at least since the Middle Neolithic, as evidenced by the finds of Punta Spalmatore and - with less certainty - Grotta Azzurra, for which the materials are attributed to the Middle Copper Age [Mannino, 1979; Mannino and Ailara, 2016]. The modern tourist village at Punta Spalmatore largely destroyed the prehistoric settlement, but obsidian and ceramics dated between the middle and final phase of the Sicilian Neolithic were recovered [Mannino, 1998], revealing for the first time, in 1997, the occupation of the island in these phases. The occupation during the Copper Age is attested not only in the caves San Francesco and Azzurra, on the southern side of the island [Mannino and Ailara, 2014; 2016], but also in Piano dei Cardoni [Spatafora, 2009; 2016] with materials dated to the Early and Middle phases of the Sicilian Copper Age (4th millennium BCE) (Figure 3). The 2018-2020 fieldwork campaigns at Piano dei Cardoni revealed the presence of a settlement and a funerary area with a megalithic stone tomb [Speciale et al. submitted]. Although a clear floor layer for the settlement has not yet been found, the site preserves some remains of wall structures, mostly made by earthen elements, some pits, and several tools for daily activities. Underneath these structures, the semi-underground megalithic funerary structure was found (Figure 4).

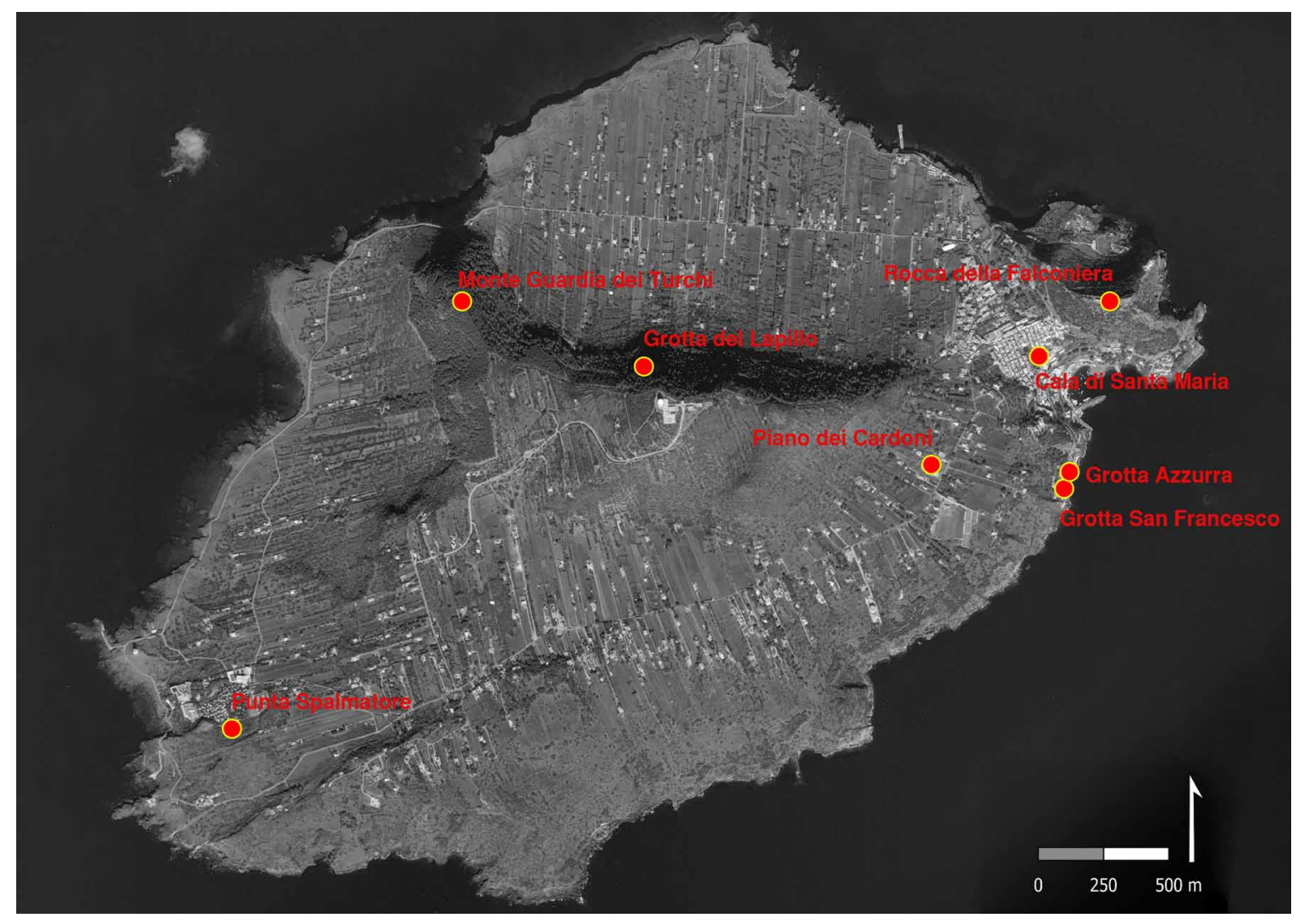

Figure 3. Ustica island. Distribution of the sites cited in the text.

Ceramics retrieved during these last excavations have been grouped into 5 main ceramic wares, based on surface appearance and treatment:

- Dark burnished ware, which shows black to brown irregular spots on a burnished surface;

- Red burnished ware, known as Diana style, distinguished from the previous ware by being mostly red or with irregular black spots on a red burnished surface;

- Incised and burnished ware, with linear incision on a burnished surface, which might be black to brown to red;

- Red painted ware, where the red paint might be applied on a white slip, making it similar to Bande Rosse/Serra d'Alto style ceramics, or directly on a smoothed surface;

- Some other vessels present a solely smoothed surface ranging black to brown to red. 


\section{Exploitation Georesources in Piano dei Cardoni}

Based on the ceramic wares encountered, the site lifespan can be mostly set between Middle Neolithic and an early phase of Late Neolithic, mid-5th millennium BC [Speciale et al., 2019], in line with the occupation of other areas in the north-western part of Sicily and Aeolian islands [Tiné and Tusa, 2012; Cavalier, 1979; Martinelli and Quero, 2013; Traverso, 2012]. Bioarchaeological remains (animal bones and vegetal remains) are also preserved and are currently under study [Speciale et al., 2021b].

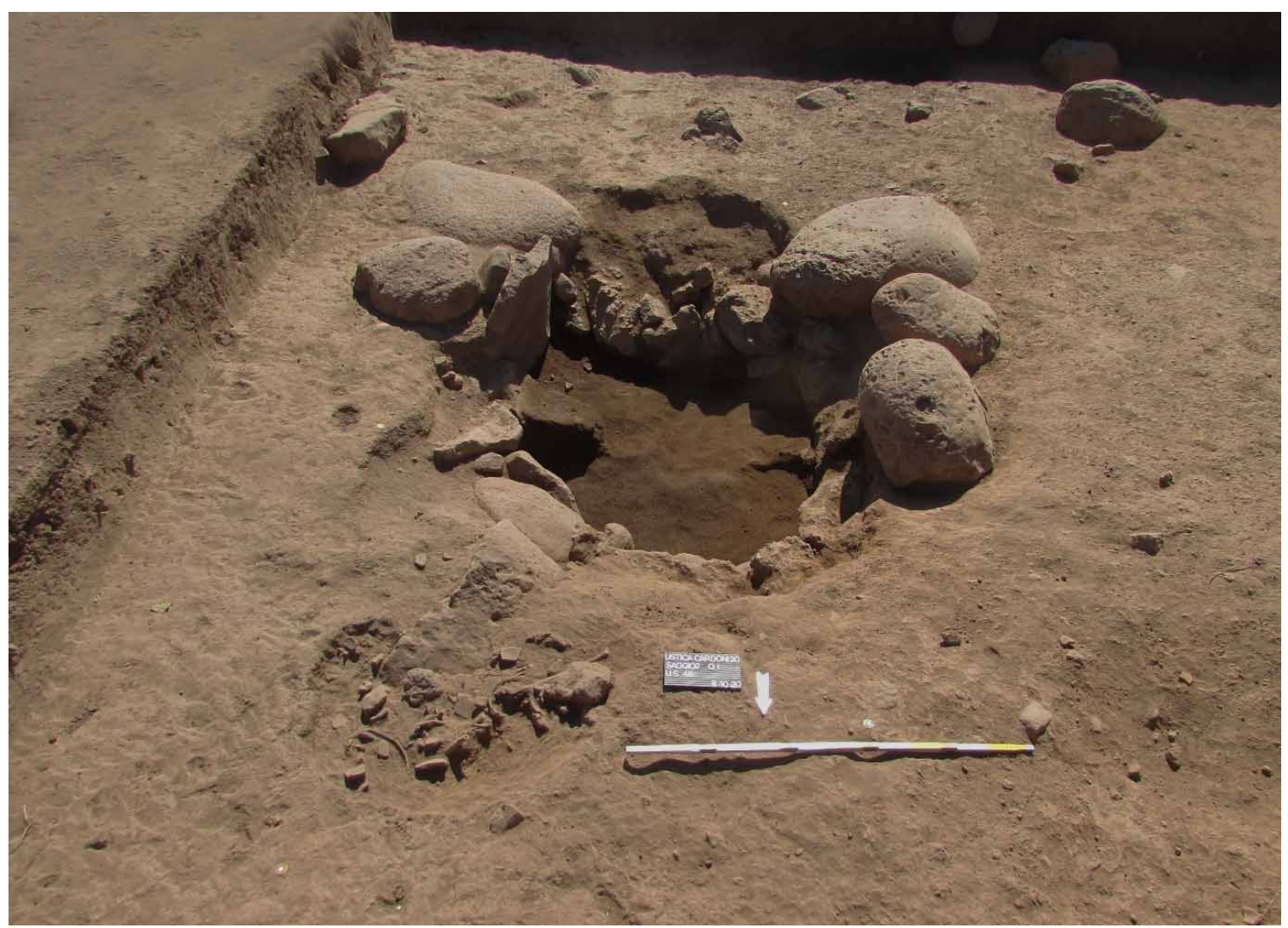

Figure 4. View of the sepulchral area from North.

\section{Lithic tools}

\subsection{Obsidian - materials and methods}

The functional study of obsidian lithic artefacts is still ongoing. A total of 41 obsidian artefacts were selected from the record of 2018 and 2019 investigations. Samples were then analysed by K. Freund. More detailed information on the use of pXRF is provided in Tykot and Foresta Martin [2020].

\subsection{Obsidian - results}

The detailed results of the analysis are published in Speciale et al. in press 2021a. The obsidian findings from the Piano dei Cardoni stratigraphic excavation are of good source quality, while from the surface findings lower quality obsidian raw material is attested. Of the 41 analyzed artefacts employing the pXRF, 39 can be traced to the Gabellotto Gorge sub-source on the island of Lipari. The other two obsidian items are from Pantelleria, but they belong to a random collection from the surface and they cannot be attributed to a specific chronology. The only reliable source for this phase of Piano dei Cardoni is the island of Lipari. 


\section{Claudia Speciale et al.}

\subsection{Chert - materials and methods (Table 1)}

Based on macroscopic observation, the chert of the artefacts found at Piano dei Cardoni is mainly of the finegrained type and only a few specimens are coarse-grained. A preliminary observation with a stereoscopic microscope (8X and 100X) [Tringham et al., 1974] has been performed.

Products have been divided into four broad categories: laminar, flakes, fragments and angular waste. Out of a total of 81 artefacts, there are 33 laminar products, 10 flakes, 7 fragments and 31 angular waste, as detailed, with percentages (italic), in tab. 1 . Among the laminar products, 4 are entire, 8 are proximal fragments, 19 are mesial and 2 are distal. Laminar products range from 6 to $18 \mathrm{~mm}$ in width, with a mean value of $11 \mathrm{~mm}$. The surface of the artefacts is fresh for the $80,2 \%$ of the total; 11 artefacts ( 6 are laminar), that is the $18,5 \%$ of the total, are burned and only 1,2\% shows a patina. Artefacts are generally unretouched, with the exception of 6 laminar products, among which 2 have been recognized as sickle elements. Remains of the cortex are almost totally absent on the whole assemblage. Provenance of chert is highly difficult to assess, despite new methods are developing (see i.e. [Gurova et al., 2021; Muntoni et al., 2021]. The preliminary analysis on Piano dei Cardoni tools does not allow for the moment to determine their provenance.

\begin{tabular}{ccccc} 
Laminar & Flakes & Fragments & Angular waste & Tot. \\
\hline 33 & 10 & 7 & 31 & 81 \\
\hline 40,7 & 12,3 & 8,6 & 38,3 & 100 \\
\hline
\end{tabular}

Table 1. Ustica, Piano dei Cardoni. Synthetic typology of the chert tools and waste collected in 2018-2019 campaign; percentage are in italics.

\subsection{Chert - results}

The analysis revealed the good preservation of the surface for the future planning of use-wear analysis with a high-magnification approach [Keeley 1980] and identified 4 artefacts probably exploited as sickle elements (Figure 5.a-d). The distribution of the polish on the surface of the inserts suggests, at a preliminary observation in "low power" approach, that they were probably diagonally hafted, as described and detailed in Mazzucco et al. [2018 and 2020] likely attesting here to the harvesting tradition, characterized by a curved sickle used for cutting at a low and middle height. Two of the possible sickle elements (Figure 5.b and 5.d) show a peculiarity: the polished surface is just one of the two faces, suggesting that the elements have been intentionally (?) removed from two original sickle inserts or, less probably, that a post-depositional surface modification (in this case resulting in a surface similar to a cereal micropolish, when observed at low magnification) affected only one of the two faces of the fragments. Final products, such as proximal, mesial and distal parts of blade(let)s are the main category of the chert finds (40\%), while by-products from knapping representing a similar percentage (38\%), suggest modest or sporadic knapping activity on the site. In Figure 5 we present a selection of the variety of chert reaching the site. There is a clear preference for very fine-grained varieties, but a coarse-grained variety is also present, as 5c (selected as sickle element) and 5e. Chert is absent on Ustica and Lipari and we hypothesize that it was imported from the area of Palermo or even from Southern Italy. Further analyses on possible chert sources from Sicily may help confirm this.

\subsection{Pumice, lavas, tuffs and sedimentary rocks - materials and methods (Table 2)}

66 lithic tools were collected and divided into categories according to their morphology and macroscopic wear traces. Despite grinding tools attracting increasing attention from researchers, there is no shared agreement on the use of the terms to define the tools, probably due to the large number of shapes and local variables (see i.e. [Lucarini and Radini, 2021; Hamon, 2008; Dietrich et al., 2020]. Some $\mathrm{cm}^{3}$ of 20 tools were then sampled, analyzed 
Exploitation Georesources in Piano dei Cardoni

\begin{tabular}{|c|c|c|c|c|c|c|c|c|}
\hline Name & $\begin{array}{l}\text { Sample } \\
\text { ID }\end{array}$ & Description & Lithology & Length & Width & Thickness & $\begin{array}{l}\text { Total } \\
\text { number }\end{array}$ & $\begin{array}{l}\text { N. of } \\
\text { samples }\end{array}$ \\
\hline $\begin{array}{l}\text { Lower } \\
\text { grinder }\end{array}$ & 7,11 & $\begin{array}{l}\text { It is mainly ovoid in shape. Also } \\
\text { called "quern" or "slab", used as a } \\
\text { basis for grinding of various } \\
\text { transformable substances - } \\
\text { (it is completed with the presence } \\
\text { of an upper grinder) }\end{array}$ & $\begin{array}{l}\text { Monte } \\
\text { Guardia dei } \\
\text { Turchi } \\
\text { basaltic } \\
\text { lavas }\end{array}$ & $7.5>17.5$ & $7>17.5$ & $3.5>11.5$ & 4 & 2 \\
\hline $\begin{array}{l}\text { Small } \\
\text { upper } \\
\text { grinder }\end{array}$ & $6,8,9$ & $\begin{array}{l}\text { It has various shapes and a length } \\
\text { under } 15 \mathrm{~cm} \text {, also called "hand } \\
\text { grinder". Used together with a lower } \\
\text { grinder for the crushing of } \\
\text { transformable substances through } \\
\text { a "back and forth" movement }\end{array}$ & $\begin{array}{l}\text { Cala S. Maria } \\
\text { basaltic } \\
\text { lavas, Monte } \\
\text { Guardia dei } \\
\text { Turchi } \\
\text { basaltic } \\
\text { lavas }\end{array}$ & $5.5>15$ & $4.5>14$ & $1.2>6$ & 11 & 3 \\
\hline $\begin{array}{l}\text { Big } \\
\text { upper } \\
\text { grinder }\end{array}$ & 15 & $\begin{array}{l}\text { It has various shapes and a length } \\
\text { over } 15 \mathrm{~cm} \text {, also called "hand } \\
\text { grinder". Used together with a lower } \\
\text { grinder for the crushing of } \\
\text { transformable substances through } \\
\text { a "back and forth" movement }\end{array}$ & $\begin{array}{l}\text { Monte } \\
\text { Guardia } \\
\text { dei Turchi } \\
\text { basaltic } \\
\text { lavas }\end{array}$ & $15>24$ & $13>14$ & $7>12$ & 2 & 1 \\
\hline Pestle & 14 & $\begin{array}{l}\text { It is pseudo-cylindrical in shape. } \\
\text { Used to crush substances such as } \\
\text { herbs or spices etc. in a mortar. } \\
\text { Usually it is more flattened in the } \\
\text { blunt part }\end{array}$ & $\begin{array}{l}\text { Cala S. Maria } \\
\text { basaltic } \\
\text { lavas }\end{array}$ & 7 & 6 & 5 & 1 & 1 \\
\hline Mortar & / & $\begin{array}{l}\text { It is generally rounded in shape. } \\
\text { Used as a basis for pounding various } \\
\text { substances. The dimensions are } \\
\text { smaller than the millstones and it is } \\
\text { likely to be used for different } \\
\text { substances }\end{array}$ & 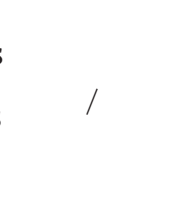 & $7>8$ & 7 & $3.5>5$ & 3 & 0 \\
\hline Percussor & / & $\begin{array}{l}\text { It is usually a pebble with a rounded or } \\
\text { cylindrical shape. Used as a "hammer" } \\
\text { or as an intermediate tool for the } \\
\text { production of other lithic tools. It is } \\
\text { possible to recognize it according to } \\
\text { wear traces in the final part }\end{array}$ & r & $5>10$ & $3>4.5$ & $2.5>4$ & 2 & 0 \\
\hline Polisher & 5,10 & $\begin{array}{l}\text { It is usually a pebble with a rounded } \\
\text { shape. It is used to smooth and } \\
\text { polish surfaces of various objects, } \\
\text { such as pots or polished stone } \\
\text { artifacts. } \\
\text { It is recognizable by the flat and } \\
\text { smooth shape of the lower surface }\end{array}$ & $\begin{array}{l}\text { Cala S. Maria } \\
\text { basaltic } \\
\text { lavas }\end{array}$ & $3.5>8.5$ & $2.7>7.5$ & $1>3.5$ & 22 & 2 \\
\hline Hatchet & 12 & $\begin{array}{l}\text { It is rectangular or trapezoidal in } \\
\text { shape. The tool was probably used } \\
\text { as wood hatchet or for agricultural } \\
\text { purposes. }\end{array}$ & $\begin{array}{l}\text { Cala S. Maria } \\
\text { basaltic } \\
\text { lavas }\end{array}$ & $7.2>12.5$ & $4>7.5$ & $0.5>2.5$ & 9 & 1 \\
\hline $\begin{array}{l}\text { Fishing } \\
\text { net } \\
\text { weights }\end{array}$ & / & $\begin{array}{l}\text { It is a rounded or oval stone with } \\
\text { a polished circular perforation, } \\
\text { probably used for the net thread }\end{array}$ & / & $4.5>8$ & $4>4.5$ & $1.5>3$ & 2 & 0 \\
\hline Other & $1,2,3,4$ & $\begin{array}{l}\text { Big rock fragments and } \\
\text { tuffs used for the enclosure } \\
\text { system of the tomb }\end{array}$ & $\begin{array}{c}\text { Cala S. Maria } \\
\text { breccias, M. } \\
\text { Costa del } \\
\text { Fallo tuffs, } \\
\text { M. Guardia } \\
\text { dei Turchi } \\
\text { basaltic } \\
\text { lavas }\end{array}$ & / & / & / & 4 & 4 \\
\hline $\begin{array}{l}\text { Pumice } \\
\text { tools }\end{array}$ & $\begin{array}{l}13,15 \\
16,17 \\
18,19\end{array}$ & $\begin{array}{l}\text { Small pumice pieces, usually } \\
\text { with a smoothed face }\end{array}$ & $\begin{array}{l}\text { Grotta del } \\
\text { Lapillo }\end{array}$ & $3.2>6$ & $4>5.5$ & $3>4.5$ & 6 & 6 \\
\hline
\end{tabular}

Table 2. Ustica, Piano dei Cardoni. Typology of the volcanic tools with description, provenance of the raw materials, ranges of length, width and thickness in cm, total number of the tools per category collected in 2018-2019 campaign, total number of the sampled specimens for microscopic analyses. 


\section{Claudia Speciale et al.}

and described according to their lithology to assess provenance and raw material selection. Among these samples, 6 belong to the pumice tools and 13 to the other volcanic tools. At least one tool was sampled for each category, except for mortars, percussors and fishing net weights for the difficulty of sampling without creating relevant damage. Pumice tools were all analyzed because of their potential provenance from the island of Lipari.

The lithological analysis of the specimens was carried out through the observation of their mineralogical and textural macroscopic characters on rupture surfaces exposed for this purpose, supplemented, where necessary, by observations made with the aid of a 10x magnifier lens or a binocular microscope with a $7.5 x$ to $60 x$ continuous zoom.
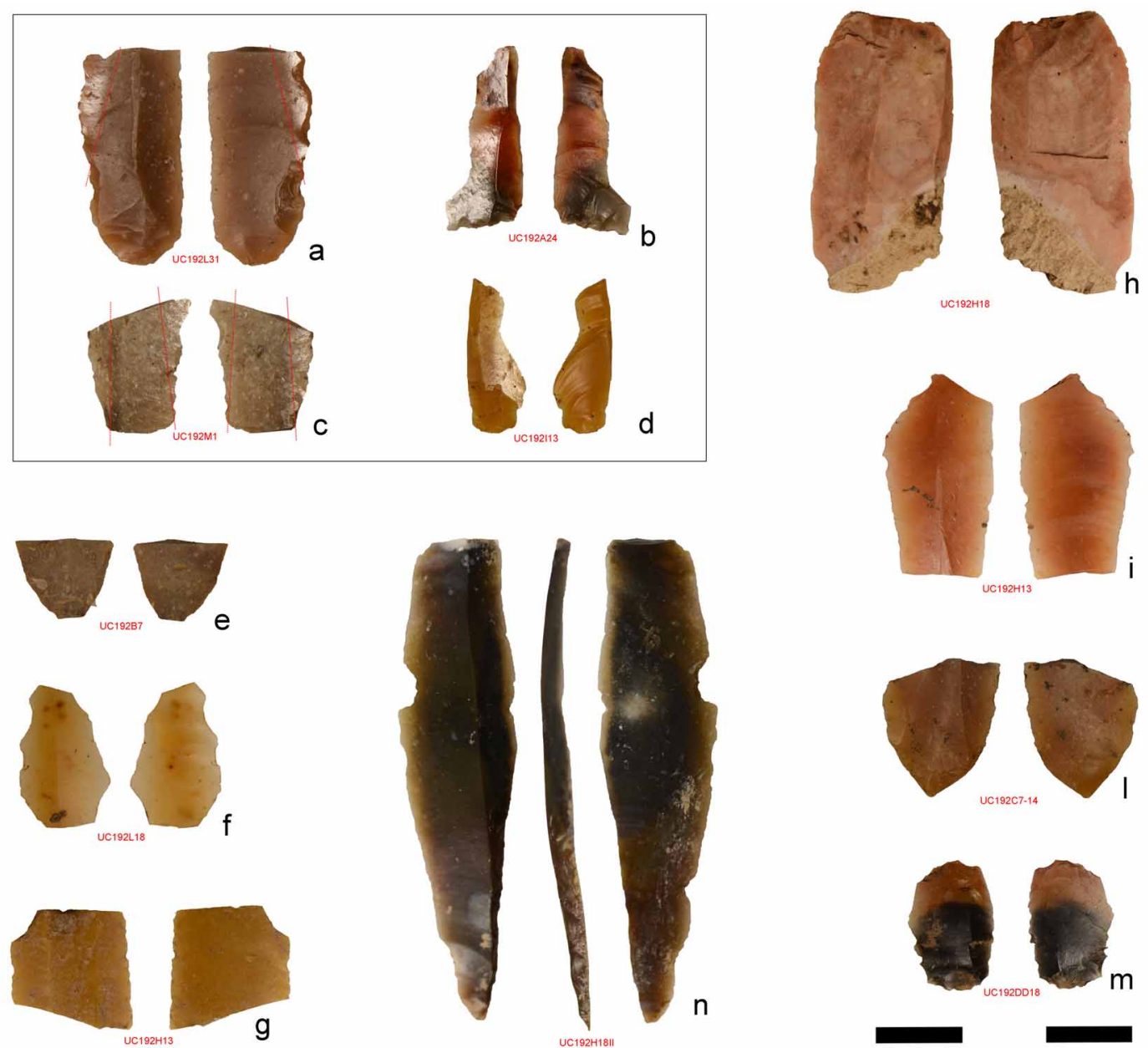

(1)

Figure 5. Ustica, Piano dei Cardoni. Chipped artefacts (a-d, probable sickle elements; e-m, proximal and medial fragments of blades and flakes; $n$, backed tool with steep unifacial retouch on the lateral edge). Partial selection of the variety of the (imported) raw material.

\subsection{Pumice - results (Figure 6g)}

Six pumice tools (ns. 13, 15, 16, 17, 18 and 19) were macroscopically analyzed. All the samples are grey/greyish pumice lapilli with a variable degree of vesiculation, aphyric or with rare phenocrysts of feldspar (plagioclase and anorthoclase) and femics (pyroxene and/or amphibole); samples n. 15 and 17 have clear signs of mechanical abrasion. The provenance of the raw material is clearly traceable to the trachytic pumice-fall and -flow deposits of the Grotte del Lapillo unit (420 ka [de Vita et al., 1998]), widely exposed on the island, in the central ridge of hills and in the south-western corner of Piano dei Cardoni-Oliastrello plain. The mineralogical paragenesis of the pumice clasts allows us to exclude their provenance from sources outside Ustica. 


\section{Exploitation Georesources in Piano dei Cardoni}

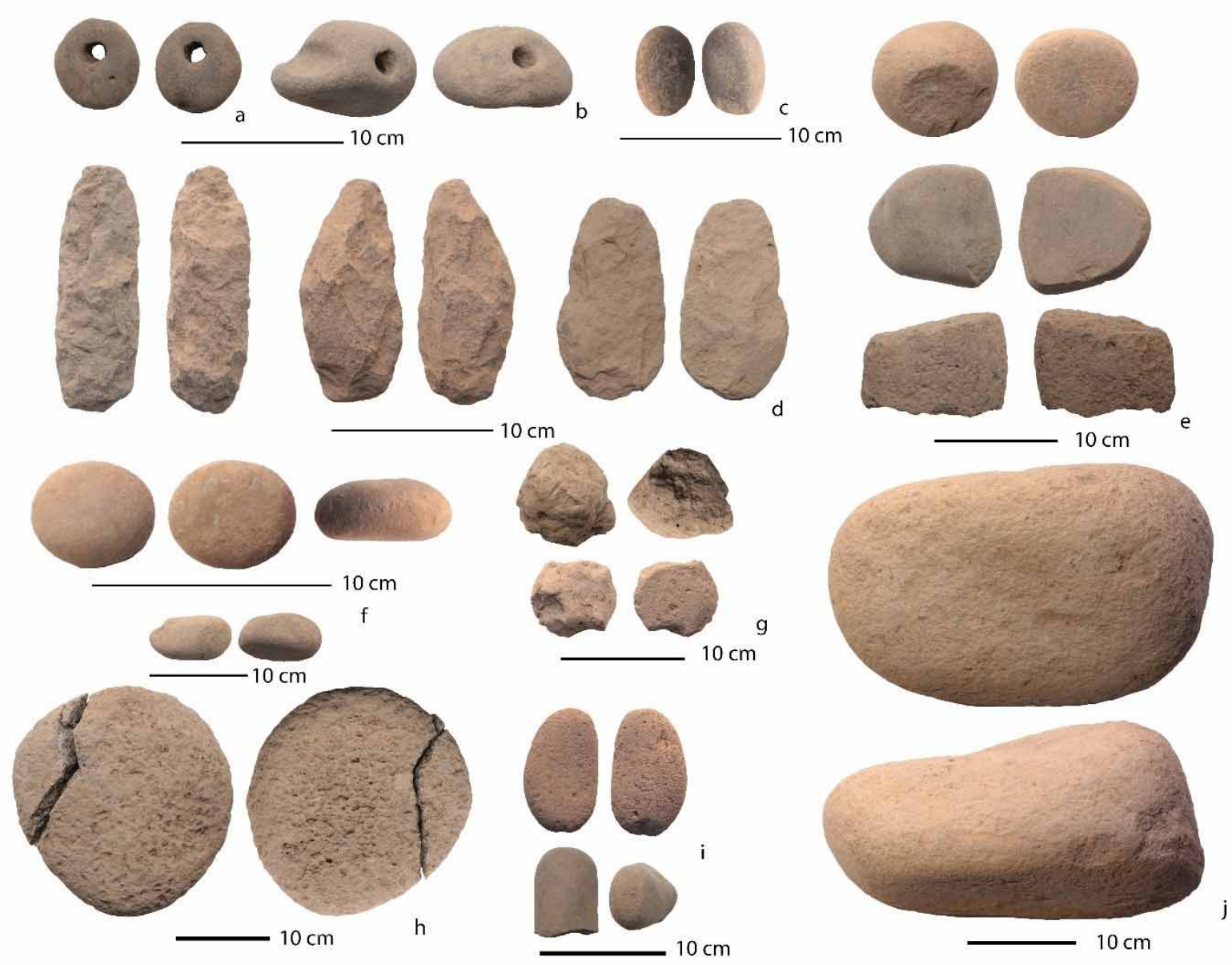

Figure 6. Typology of lavastone tools: a) Fishing net weights; b) Percussor; c) Small upper grinders; d) Hatchets; e) Polishers; f) Pumice tools; g) Mortar; h) Pestles; i) Big upper grinder.

\subsection{Lavas, tuffs and sedimentary rocks - results (Figure 6a-f, h-i)}

Two out of four samples (ns.1 and 2) from the tomb are composed of a heterometric breccia with lava fragments and carbonate cement, and a carbonate clast, consisting of a thin stratified calcarenite, with both detritic and organogenic carbonate elements and minute volcanic clasts. These probably derive from the Unit of Cala S. Maria Breccias (de Vita, 1993), which is related to the reworking of Cala S. Maria lavas in a submarine environment during the Crotonian (isotopic stage 9 of [Shackleton and Hopdike, 1973]) transgressive-regressive cycle, responsible for the formation of the first order marine terrace of about $350 \mathrm{ka}$ [de Vita and Orsi, 1994; de Vita et al., 1998]. One sample (n. 3) is a tuff fragment, consisting of a lithified, massive and poorly sorted coarse ash deposit, with subangular to sub-rounded, basaltic scoriaceous lapilli, lithic fragments and loose crystals. This sample is likely correlated to the unit of M. Costa del Fallo Tuffs (approx. $500 \mathrm{ka}$ ), or the Falconiera Tuff (130 ka [de Vita et al., 1998]). The last sample from the tomb (n. 4) is a fragment of a subaerial basaltic lava with scarce microphenocrysts of plagioclase and iddingsitized olivine, with altered carbonate encrustations. It very likely belongs to the M. Guardia dei Turchi unit (520 ka [de Vita, 1993; de Vita et al., 1998]), which was partially submerged by the sea during the formation of the first order marine terrace [de Vita, 1993; de Vita and Orsi, 1994].

Samples 5, 9, 10, 12 and 14, used for hatchets, upper grinders, polishers and pestles, are submarine basaltic lavas, compact or micro-vesiculated, aphanitic or microcrystalline with abundant plagioclase and subordinate olivine crystals, and probably belong to the unit of Cala S. Maria lavas or perhaps to the submarine part of the M. Guardia dei Turchi unit (de Vita, 1993). Subaerial basaltic lava fragments, well vesiculated, with plagioclase microphenocrysts 


\section{Claudia Speciale et al.}

from M. Guardia dei Turchi unit were used for the lower grinders n.7 and 11 and the upper grinders n.6 and 8; sample $n .8$ is also characterized by the neoformation of alteration minerals within the vesicles, while sample $n$. 11 contains iron oxides deposited in the vesicles.

The lithologic characteristics of all the samples, widely represented in the rocks exposed at Ustica, reveal that all the raw materials in the Piano dei Cardoni site are from local georesources.

\section{Ceramics}

\subsection{Materials and methods}

Based on the ware classification, 30 samples were selected for petrographic examination to shed light on the raw material catchment area on the island and the possible circulation of finished ceramics from Sicily or other Sicilian islands. Samples cover the most common wares found in the island and other contemporary contexts: dark burnished (13 samples), red burnished (3) incised and burnished (7 samples), slipped and painted (2), painted (2 samples) and smoothed (3 samples) wares (Table 3, Figure 7). Polarized light microscopy on thin-section (0.03 mm thickness) was performed by a Leica DM-SLP microscope equipped with a Leica digital camera (Leica IM100 Image Manager software). The use of transmitted (polarized) light microscopy on thin sections $(0.03 \mathrm{~mm})$ for the study of the ceramic material, as well known, allows the definition of the mineralogical composition and various textural parameters referable to the coarser aplastic inclusions and the fine plastic groundmass [Quinn, 2009; Hunt, 2016].

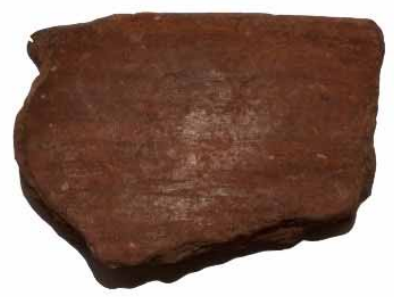

a

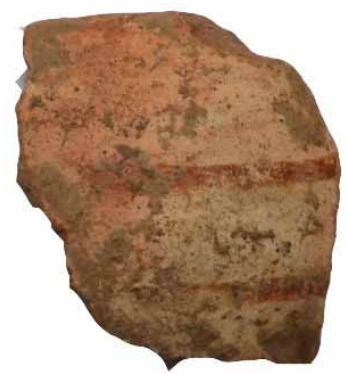

d

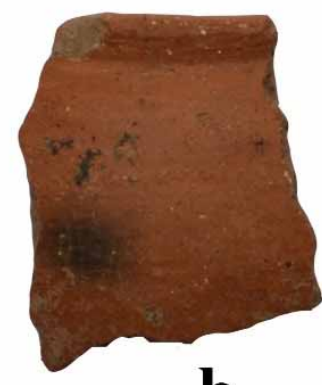

b

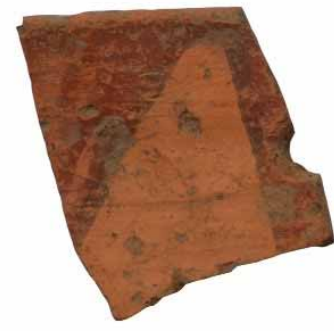

e

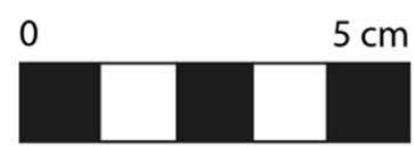

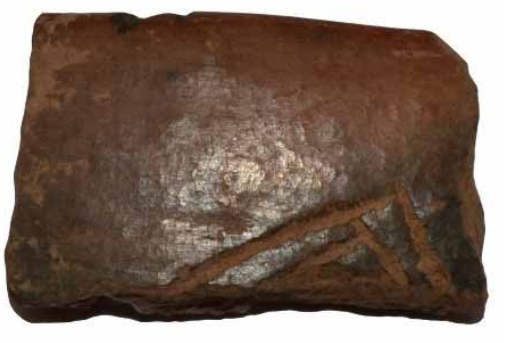

c

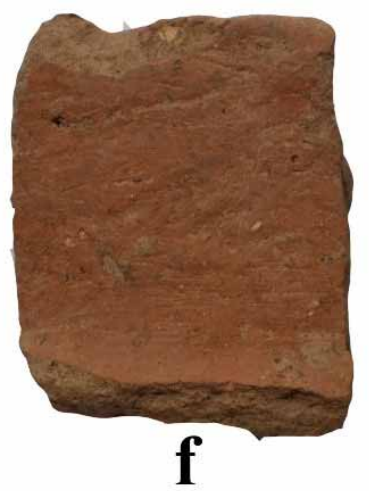

Figure 7. Pictures of representative samples for the wares considered in the study: a) UST19/029, dark burnished ware; $b$ ) UST19/022, red burnished ware; c) UST19/025, burnished and incised ware; d) UST19/003, painted ware, red painting on white slipped background; e) UST19/013, painted ware, red painting on unslipped background; f) UST19/015, smoothed ware. 
By recognizing the sand-sized monomineralic granules and lithic fragments and by evaluating their size, morphology and relative frequency, it is possible to acquire insights on raw materials sourcing and the overall production process [Whitbread, 1995; Gliozzo, 2020; Montana, 2020].

From the petrographic analysis of the above-described Neolithic ceramic set, it appears that the majority of the studied samples (29 out of 30 ) belong to the same fabric and on the basis of their lithology can be considered as a local production characterized by abundant volcanic inclusions of basaltic nature. Based on textural aspects (e.g., approximate firing temperature, aplastic inclusions abundance and size distribution) Fabric 1 can be further clustered into five subgroups.

\begin{tabular}{|c|c|c|c|c|}
\hline \multicolumn{2}{|c|}{ Sample \# } & \multirow{2}{*}{$\begin{array}{c}\text { Sector } \\
27 \mathrm{D}\end{array}$} & \multirow{2}{*}{$\begin{array}{c}\text { SU } \\
3\end{array}$} & \multirow{2}{*}{$\begin{array}{c}\text { Ware } \\
\text { dark burnished }\end{array}$} \\
\hline UST 19/ & 001 & & & \\
\hline UST 19/ & 002 & $27 \mathrm{D}$ & 3 & incised and burnished \\
\hline UST 19/ & 003 & 27D & 3 & slipped and painted \\
\hline UST 19/ & 004 & $26 \mathrm{D}$ & 3 & dark burnished \\
\hline UST 19/ & 005 & $26 \mathrm{D}$ & 3 & dark burnished \\
\hline UST 19/ & 006 & $26 \mathrm{D}$ & 3 & dark burnished \\
\hline UST 19/ & 007 & $26 \mathrm{D}$ & 3 & incised and burnished \\
\hline UST 19/ & 008 & $26 \mathrm{D}$ & 3 & incised and burnished \\
\hline UST 19/ & 009 & $26 \mathrm{D}$ & 3 & slipped and painted \\
\hline UST 19/ & 010 & $25 \mathrm{D}$ & 3 & dark burnished \\
\hline UST 19/ & 011 & $25 \mathrm{D}$ & 3 & painted \\
\hline UST 19/ & 012 & $25 \mathrm{D}$ & 3 & red burnished \\
\hline UST 19/ & 013 & 29D & 7 & painted \\
\hline UST 19/ & 014 & 29D & 7 & dark burnished \\
\hline UST 19/ & 015 & 29D & 7 & smoothed \\
\hline UST 19/ & 016 & 29D & 7 & smoothed \\
\hline UST 19/ & 017 & 30D & 7 & incised and burnished \\
\hline UST 19/ & 018 & 30D & 7 & incised and burnished \\
\hline UST 19/ & 019 & 30D & 7 & dark burnished \\
\hline UST 19/ & 020 & 30D & 7 & dark burnished \\
\hline UST 19/ & 021 & 30D & 7 & dark burnished \\
\hline UST 19/ & 022 & $28 \mathrm{D}$ & 7 & red burnished \\
\hline UST 19/ & 023 & $28 \mathrm{D}$ & 7 & dark burnished \\
\hline UST 19/ & 024 & $28 \mathrm{D}$ & 7 & dark burnished \\
\hline UST 19/ & 025 & $34 \mathrm{D}$ & 10 & incised and burnished \\
\hline UST 19/ & 026 & $34 \mathrm{D}$ & 10 & incised and burnished \\
\hline UST 19/ & 027 & 31D & 8 & dark burnished \\
\hline UST 19/ & 028 & 27D & 3 & smoothed \\
\hline UST 19/ & 029 & 31D & 8 & dark burnished \\
\hline UST 19/ & 030 & $28 \mathrm{D}$ & 7 & red burnished \\
\hline
\end{tabular}

Table 3. List of ceramic vessels sampled for petrographic examination. 


\section{Claudia Speciale et al.}

The detailed petrographic descriptions of the microfabric in which the analysed samples have been classified are reported as supplementary material (Supplementary 1), while a schematic description of fabrics is given in Table 4. Fabric 1a comprises most of the studied samples $(n=16)$. They were fired at a relatively higher temperature (around $800^{\circ} \mathrm{C}$ ) as can be inferred from the low optical activity of the groundmass. This microscopic fabric is distinguished by the coarser average size and abundance (packing $=15-20 \%$ area) of the volcanic aplastic inclusions (Figure 8AB). On the contrary, in Fabric $1 \mathrm{~b}(\mathrm{n}=4)$, aplastic inclusions are less abundant (10\% area) and finer (Figure $8 \mathrm{C})$. Fabric $1 c(n=6)$ includes samples characterized by the same volcanic aplastic inclusions (qualitatively and quantitatively), being the firing temperature visibly lower than fabrics $1 \mathrm{a}$ and $1 \mathrm{~b}$ (estimated around $700^{\circ} \mathrm{C}$ by the optical activity of the groundmass) (Figure $8 \mathrm{D}$ ). Fabric $1 \mathrm{~d}$ is characterized by a ceramic body showing numerous cloths composed of microcrystalline calcite, mostly with irregular shape (Figure 8E-F). Sample UST 19/010 compositionally fits with Fabric 1b, nonetheless, it appears strongly overfired. Only the sample UST 19/013 constitutes Fabric 2, being considerably different as regards the composition of the aplastic inclusions and also concerning the textural features. It shows the typical microscopic appearance of calcareous clayey raw materials fired at high temperature firing (higher than $800^{\circ} \mathrm{C}$ ). The inclusions are all of sedimentary nature and fragments of a volcanic nature are totally absent (Figure 9A-B).

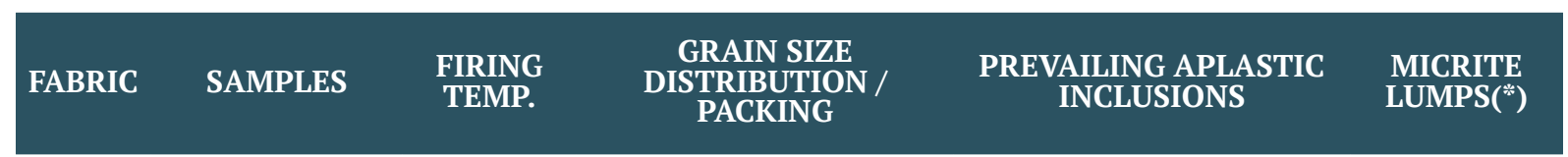

UST19/001, 002, 004, 005, 006, 007,
$1 \mathrm{a} \quad 008,016,017,020$, 021, 022, 023, 024, about serial $(0.03-3 \mathrm{~mm})$ $800^{\circ} \mathrm{C}$ prevailing: 0.3-0.5 mm

Volcanic (plagioclase, basaltic lava fragments, packing: $15-20 \%$ (area) clinopyroxene, olivine)

YES (very few) 025, 027, 028

\begin{tabular}{|c|c|c|c|c|c|}
\hline $1 b$ & $\begin{array}{l}\text { UST19/003, 011, } \\
\text { 018, } 030\end{array}$ & $\begin{array}{l}\text { about } \\
800^{\circ} \mathrm{C}\end{array}$ & $\begin{array}{l}\text { serial }(0.03-2 \mathrm{~mm}) \\
\text { prevailing: } 0.1-0.2 \mathrm{~mm} \\
\text { packing: } 10 \% \text { (area) }\end{array}$ & $\begin{array}{l}\text { Volcanic (plagioclase, } \\
\text { basaltic lava fragments, } \\
\text { clinopyroxene, olivine) }\end{array}$ & NO \\
\hline $1 \mathrm{c}$ & $\begin{array}{l}\text { UST 19/009, } 012 \text {, } \\
015,019,022,026\end{array}$ & $\begin{array}{l}\text { about } \\
700^{\circ} \mathrm{C}\end{array}$ & $\begin{array}{l}\text { serial }(0.03-2 \mathrm{~mm}) \\
\text { prevailing: } 0.2-0.5 \mathrm{~mm} \\
\text { packing: } 15-20 \% \text { (area) }\end{array}$ & $\begin{array}{l}\text { Volcanic (plagioclase, } \\
\text { basaltic lava fragments, } \\
\text { clinopyroxene, olivine) }\end{array}$ & $\begin{array}{l}\text { YES } \\
(\text { few) }\end{array}$ \\
\hline $1 d$ & UST 19/014, 029 & $\begin{array}{l}\text { about } \\
700^{\circ} \mathrm{C}\end{array}$ & $\begin{array}{l}\text { serial }(0.03-3 \mathrm{~mm}) \\
\text { prevailing: } 0.3-0.5 \mathrm{~mm} \\
\text { packing: } 10 \% \text { (area) }\end{array}$ & $\begin{array}{l}\text { Volcanic (plagioclase, } \\
\text { basaltic lava fragments, } \\
\text { clinopyroxene, olivine) }\end{array}$ & YES (many) \\
\hline- & UST 19/010 & Overfired & $\begin{array}{l}\text { serial }(0.03-2 \mathrm{~mm}) \\
\text { prevailing: } 0.1-0.2 \mathrm{~mm} \\
\text { packing: } 10-15 \% \text { (area) }\end{array}$ & $\begin{array}{l}\text { Volcanic (plagioclase, } \\
\text { basaltic lava fragments, } \\
\text { clinopyroxene, olivine) }\end{array}$ & NO \\
\hline 2 & UST 19/013 & $\begin{array}{l}\text { about } \\
900^{\circ} \mathrm{C}\end{array}$ & $\begin{array}{l}\text { serial to bimodal } \\
\quad(0.03-0.5 \mathrm{~mm}) \\
\text { prevailing: } 0.03-0.2 \mathrm{~mm} \\
\text { packing: } 10-15 \% \text { (area) }\end{array}$ & $\begin{array}{l}\text { Sedimentary (quartz, } \\
\text { calcareous bioclasts, K- } \\
\text { feldspar, chert, } \\
\text { quartzarenite) }\end{array}$ & NO \\
\hline
\end{tabular}

Table 4. Table summarizing the characteristics of the petrographic groups described in the Supplementary material $1(*)$ Microcrystalline calcite (micrite) lumps could be originated from thermal decomposition (after the firing process) of inclusions which were originally present in the clayey raw material, or rather by secondary calcite precipitation from supersaturated percolating water which impregnated the ceramic body during the burial phase. 

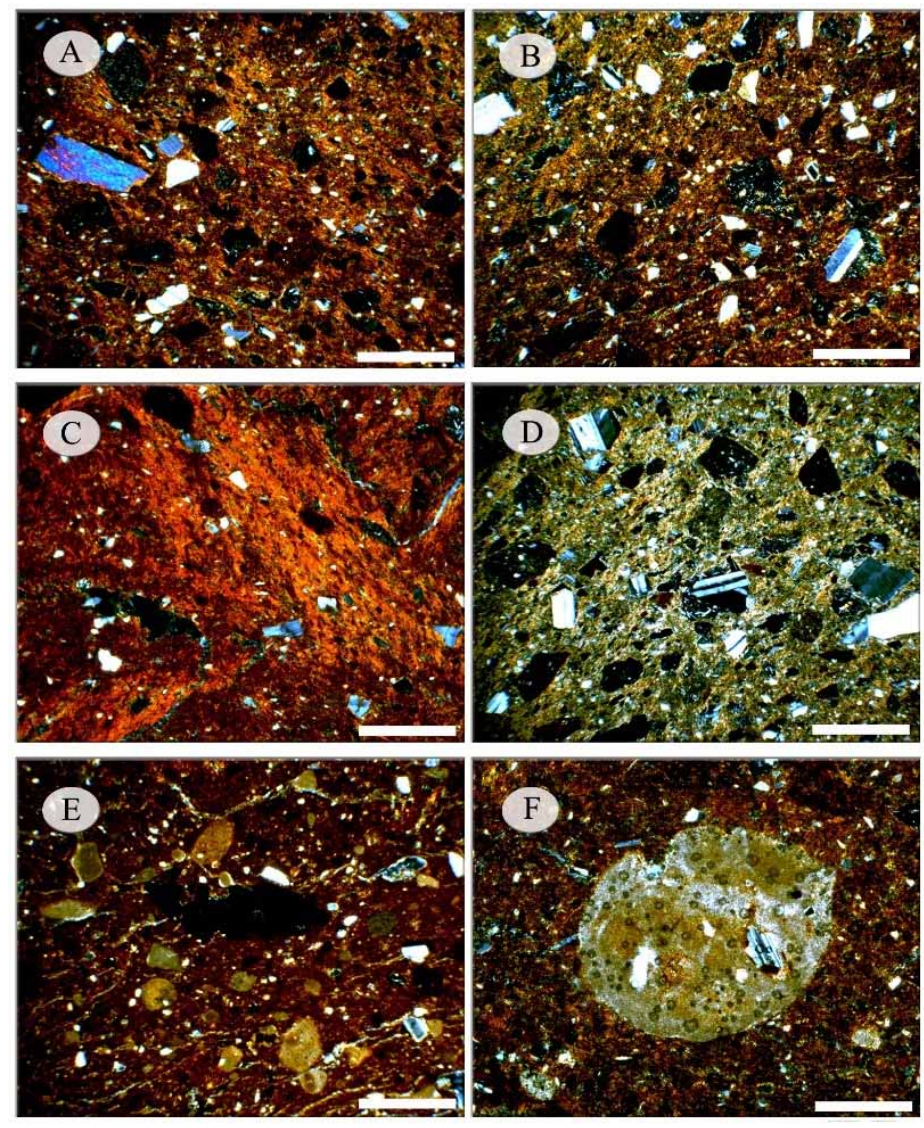

Figure 8. Thin section photomicrographs representative of the compositional and textural characteristics of the ceramic finds under study, recognized as local productions: a) Fabric 1a, sample UST 19/005 (XPL, scale bar = $0.5 \mathrm{~mm}$ ); b) Fabric 1a, sample UST 19/028 (XPL, scale bar = 0.5 mm); c) Fabric 1b, sample UST 19/011 (XPL, scale bar = 0.5 mm); d) Fabric 1c, sample UST 19/026 (XPL, scale bar = 0.5 mm); e) Fabric 1d, sample UST 19/014 (XPL, scale bar $=0.5 \mathrm{~mm}$ ); f) Fabric 1d, sample UST 19/029 (XPL, scale bar = $0.2 \mathrm{~mm}$ ).

\section{Discussion (Figure 10)}

\subsection{The island of the grinding stones}

Despite being a small, remote, island with limited resources, Ustica hosts a high variety of useful volcanic resources that probably made it suitable for Neolithic colonizers. The rocks used for anthropic purposes are exclusively of local lithology, easily reachable from the site. All the samples relate to units exposed close to Piano dei Cardoni area; the volcanic formations of M. Guardia dei Turchi, of the Lave and Brecce of Cala S. Maria and of the Pomici of Grotte del Lapillo. Nevertheless, the selection and choice of the tools, for their raw material and shape, beyond the knapping of the hatchets, show a varied and "specialized" typology. Subaerial lavas of M. Guardia dei Turchi which are more vesiculated, were used for the upper and lower grinders, while the underwater ones of Cala S. Maria, more compact, were used for the pestles and the hatchets. Of relevance is the presence of easily available pebbles eventually exploitable for different knapping stages of chert and obsidian products. All of this suggests the creation of tools for grain processing, but due to still ongoing archaeobotanical analysis, we cannot exclude the use of grinding tools for the processing of other vegetal resources.

The pumices seem to have been employed as an abrasive for cleaning or similar uses, as they are very rounded but with the presence of vitreous dust inside the vesicles (the pumices naturally remodelled in the sea are instead very clean). 


\section{Claudia Speciale et al.}
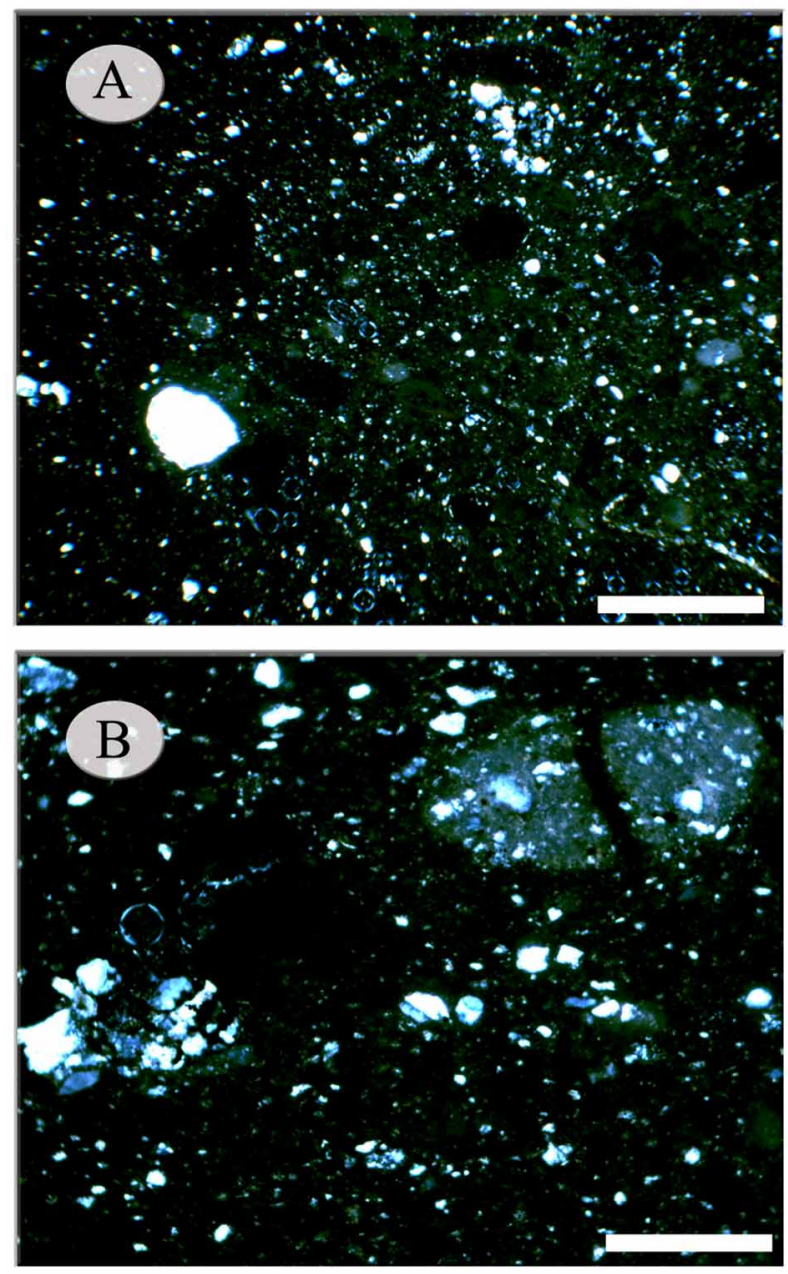

Figure 9. Thin section photomicrographs showing the characteristics of the UST 19/013 sample, the only one certainly recognized as imported among the 30 ceramic finds under study. Abundant grains of detrital quartz (angular to sub-rounded) and lithic grains (quartz and chert sandstones) of detrital sedimentary nature are visible: (A) crossed nicols, scale bar $=0.5 \mathrm{~mm}$; (B) crossed nicol, scale bar $=0.2 \mathrm{~mm}$.

Ustica is a key site for the interpretation of lithic assemblages in small islands because both raw resources (chert and obsidian) required transportation by sea from other territories. Additionally, there may have been a preferential channel of exchange and communication with the Aeolian archipelago during these first phases of the occupation of the island. Finally, it is likely that obsidian was imported as a raw material to the island, as testified by the outstanding number of big, medium, and small fragments (sometimes detected only by the $0.5 \mathrm{~mm}$ mesh) that attest to knapping activities on the site.

Obsidian in Piano dei Cardoni is the main exotic good at the site. The role of Ustica as a trading place for obsidian towards north-western Sicily can be inferred by several indicators [Speciale et al., 2021a]. At this stage, it is not possible to establish if obsidian was the primary and/or only material or if it was a complement to other exchanged goods. At the same time, Ustica resources, such as volcanic millstones or pottery, could be traded to north-western Sicily and exchanged for chert or other goods. Chert was likely imported from the area of Palermo (south-eastern Mesozoic reliefs are characterized by the presence of chert lens, nodules and beds), but due to some cultural aspects, other areas such as the Southern Apennines or the Gargano subregion cannot be excluded. If an intentional modification of used tools is confirmed by future analyses, such as that inferred for two fragments hypothetically originating from sickle elements, it can be interpreted as a need to recycle a raw material naturally lacking on the 


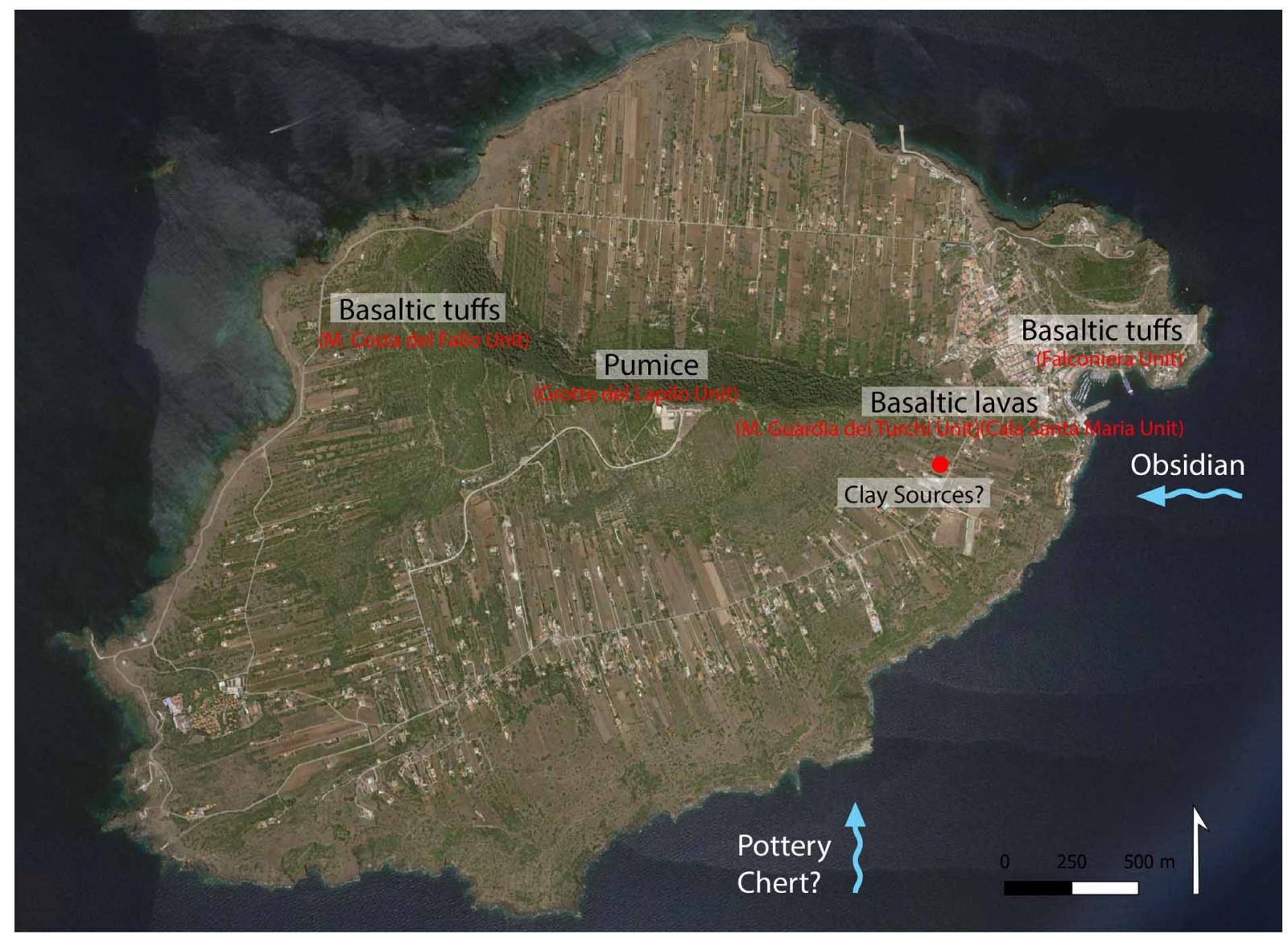

Figure 10. Distribution of the exploited local and non-local georesources from the site of Piano dei Cardoni. The red dot shows the position of the site.

island and probably preferred for specific purposes (functional analysis will explore this possibility). Reuse of sickle elements and double use of the same inserts (suggested by the glossy appearance of sickle elements on both the edges), for example, was a technique for prolonging the use of the flint tools seen also at Lipari during the Late Neolithic at Contrada Diana [Martinelli, 2000]. On the contrary, at a preliminary stage of study, the observation of a high percentage of by-products of obsidian from Lipari may suggest an easier access to this specific raw material. A similar distribution in the preference of the chert grain size has been observed at Contrada Diana [Martinelli, 2000]. Chert analysis confirms that Ustica has more similarities to the close-to-the-source of obsidian sites, as previously supposed [Speciale et al., 2021a]. Further analyses will help in clarifying its possible source, that can now only hypothetically placed in North-Western Sicily.

\subsection{Local materials for local ceramics}

The majority of the ceramic samples examined showed inclusions (minerals and lithic fragments) that can be associated to the magmatic products characteristic of the island of Ustica [Cinque et al., 1988; de Vita et al., 1998; Peccerillo, 2005]. These ceramics can be distinguished from the coeval productions of Lipari by the absence of intermediate or acidic rock fragments that characterize the magmatism of the Aeolian Island (e.g. potassium-rich andesitic basalts, pumice, obsidian, sanidine phenocrystals) [Williams, 1980; Williams and Levi, 2008; Brunelli et al., 2013]. Furthermore, in the ceramic pastes at Ustica, the femic minerals (especially clinopyroxenes) are much less frequent than that found in pottery produced at Lipari and the plagioclase crystals are not zoned unlike those of the andesites on Lipari. 


\section{Claudia Speciale et al.}

Both compositional and textural aspects of the local ceramic paste provide interesting evidence about potters' choice in raw material sourcing. They selected clayey-sandy soils in the island developed over volcanic deposits, being low calcareous and generally rich in iron oxides. They formed after the pedological evolution of lavas and/or pyroclastic deposits weathered by exogenous agents. Colluvial sediment of this type forms preferably under favourable morphological conditions, like depressions in the bedrock, where they can reach a suitable thickness and collect a greater quantity of clay particles, which gives plasticity and workability. The lumps composed of microcrystalline calcium carbonate (micrite), which were found in several samples, could be ascribed to this process. Hardened $\mathrm{CaCO}_{3}$ concretions can form in soils by chemical precipitation from infiltration waters. They are frequently found in arid areas, where even thick layers (caliche) may form. However, in the case of the studied ceramic samples, the presence of small micrite lumps (millimetric or mostly sub millimetric) could be also interpreted as secondary (burial) calcite precipitated directly in the ceramic sherd. This hypothesis is corroborated by the presence of small plagioclase and clinopyroxene crystals incorporated in the microcrystalline calcite mass (Figure 8F).

The textural variabilities observed in the examined ceramic fabrics could be ascribed to several reasons such as different raw materials sourcing areas or to "natural" variability within the same exploitation point. Nevertheless, there is a striking continuity in using similar raw material for the manufacture of different wares across the period examined and in the tempering procedures (if any). In fact, all the petrographically recognized local ceramic pastes (fabrics) have as a common denominator the same type of volcanic aplastic inclusions (of various size, ranging from $0.04 \mathrm{~mm}$ to $2 \mathrm{~mm}$ or more).

Only the sample UST 19/013 (Fabric 2) shows the absence of volcanic inclusions and compositional/textural characteristics (concerning both the aplastic inclusions and the groundmass). This suggests that the sample was imported from North-Western Sicily, possibly from the Palermo area. Its surface treatment (a reversed triangle painted in red out of the rim, probably attributable to "tricromica" ware) makes it stand out from the other painted ceramics found at the site.

Further sampling has been planned to better picture local and possible non-local manufacture and to locate the raw material catchment areas.

\section{Conclusions}

The first results from the analyses of the georesources in the site of Piano dei Cardoni (Ustica, Italy) shed new light on the exploitation of local and non-local resources on a small volcanic island. Volcanic rocks were easily collected and were located very close to the site (in a range of 2 kilometres). They were selected to achieve the best performance of the grinding and milling tools. The elevated number of grinders, pestles and mortars testify to intense activity revolving around food/plant processing at the site. This was apparently not accompanied by a high frequency of crops, maybe due to taphonomical processes or maybe to the exploitation of wild species. The absence of obsidian resources on the island pushed human communities to import it from the Aeolian islands. Chert was also imported although its provenance remains undefined. The re-use of some chert tools leads us to believe that it was scarcer than obsidian. Pumice was collected on Ustica, probably due to local availability and good quality. Most of the ceramic products sampled so far were made using local clay sources and only one sample seems to have come from the North coast of Sicily. The study of local clayey raw materials (already in an advanced state of completion through simulations and experimental firings) and the analysis of a larger number of ceramic finds, will allow a more complete interpretation of the "production chain". In conclusion, the Neolithic inhabitants of Ustica were exploiting all the raw materials available on the island, especially volcanic rocks, while at the same time procuring more distant materials, such as obsidian and chert. Despite being preliminary, this interdisciplinary study reveals that even a distant and small island such as Ustica was not excluded from the circulation of materials and objects that in the Middle/Late phase of the Neolithic occurred in the central Mediterranean.

Acknowledgments. This investigation was conducted thanks to the project Brains2Islands, "Indagine Multidisciplinare nei Contesti Insulari Basso Tirrenici”, project Funded by FONDAZIONE CON IL SUD, project number 2015-0296. Richard 
J. Brown, is warmly acknowledged for the revision of the text and for his useful comments, which improved the quality of the manuscript. In memory of Giovanni Mannino (1929-2021), who loved the island of Ustica and opened the modern research on its prehistory. Author contribution: Conceptualization, C.S.; methodology, C.S., G.B., S.V., S.d.V.; investigation, C.S., G.B., R.M., G.M., F.M.; data curation, C.S., G.M., R.M., S.d.V., V.F., F.M.; writing-review and editing, C.S., G.M., S.d.V.; supervision, G.B., S.V.; funding acquisition, C.S., M.D.V., S.d.V. All authors have read and agreed to the published version of the manuscript.

\section{References}

Barberi, F., S. Borsi, G. Ferrara and F. Innocenti (1969). Strontium isotopic composition of some recent basic volcanites from southern Tyrrhenian sea and Sicily Channel, Contr. Mineral. And Petrol., 23, 157-172.

Barberi, F. and F. Innocenti (1980). Volcanisme Neogéne et Quaternaire. Guide a l'excursion 122-A, Soc. It. Miner. Petrol., 99-104.

Bracchitta, D. (2015). Chap. 6. The stone artefacts from the settlement at Borg in-Nadur, in Tanasi, D. and N.C. Vella (eds.), The late prehistory of Malta: essays on Borg in-Nadur and other sites, Archaeopress Archaeology series, 115-120.

Brunelli, D., S.T. Levi, P. Fragnoli, A. Renzulli, P. Santi, E. Paganelli and M.C. Martinelli (2013). Bronze Age pottery from the Aeolian Islands: definition of temper compositional reference units by an integrated mineralogical and microchemical approach, Applied Physics A, 113, 855-863.

Cannavò, V., A. Di Renzoni, S.T. Levi and D. Brunelli (2019). Protohistoric Italian Ceramics: Towards a General Fabrics Classification and Interpretation, Origini, 43, 209-234.

Cinque, A., L. Civetta, G. Orsi and A. Peccerillo (1988). Geology and geochemistry of the island of Ustica (Southern Tyrrhenian sea), Rend. Soc. It. Min. e Petr., 43, 987-1002.

Clarkson, C.J. (2008). Lithics in the landscape. Handbook of landscape archaeology, B. David and J. Thomas (eds.), Walnut Creek, CA, U.S.A.: Left Coast Press, 490-501.

Clement, C.R. and M.F. Cassino (2018). Landscape Domestication and Archaeology. In: C. Smith (ed.), Encyclopedia of Global Archaeology. Springer, Cham.

de Vita, S. (1993). Assetto geologico-strutturale ed evoluzione vulcanologica dell'isola di Ustica (stratigrafia, tettonica e meccanismi eruttivi), PhD Thesis, Napoli, 162.

de Vita, S. and G. Orsi (1994). I terrazzi marini dell'isola di Ustica (Mar Tirreno Meridionale, Italia), Mem. Descr. Carta Geol. D’It., 52, 405-406.

de Vita, S., G. Guzzetta and G. Orsi (1995). Deformational features of the Ustica volcanic area in the Southern Tyrrhenian Sea (Italy), Terra Nova, 7, 623-629.

de Vita, S., M.A. Laurenzi, G. Orsi and M. Voltaggio (1998). Application of 40Ar/39Ar and 230Th dating methods to the chronostratigraphy of Quaternary basaltic volcanic areas: the Ustica island case history, Quaternary International, 47/48, 117-127.

de Vita, S. and F. Foresta Martin (2017). The palaeogeographic setting and the local environmental impact of the 130 ka Falconiera tuff-cone eruption (Ustica island, Italy), Ann. Geophys., 60, 2, S0224.

Di Renzoni, A., G. Ayala, D. Brunelli, S.T. Levi, S. Lugli, E. Photos Jones, A. Renzulli, and P. Santi (2016). Aiding and abetting the archaeological enquiry: geochemical work-in-progress at the site of San Vincenzo, Stromboli, Aeolian Islands, Italy, in E., Photo-Jones et al. (eds.), Proceedings of the 6th Symposium of the Hellenic Society for Archaeometry, British Archaeological Reports. - International Series 2780, 167-174.

Dawson, H. (2014). Mediterranean Voyages: The Archaeology of Island Colonisation and Abandonment, Routledge, New York.

Dietrich, L., J. Meister, O. Dietrich, J. Notroff, J. Kiep, J. Heeb, A. Beuger and B. Schütt (2019). Cereal processing at Early Neolithic Göbekli Tepe, southeastern Turkey, PLoS ONE, 14, 5, e0215214.

DiNapoli, R.J., T.M. Rieth, C.P. Lipo and T.L. Hunt (2020). A model-based approach to the tempo of "collapse": The case of Rapa Nui (Easter Island), J. Archaeological Sci., 116, 105094.

Di Vito, M.A., E. Zanella, L. Gurioli, R. Lanza, R. Sulpizio, J. Bishop, E. Tema, G. Boenzi and E. Laforgia (2009). The Afragola settlement near Vesuvius, Italy: The destruction and abandonment of a Bronze Age village revealed by archaeology, volcanology and rock-magnetism, Earth Planet. Sci. Lett., 277, 3-4, 408-421. 


\section{Claudia Speciale et al.}

Fitzhugh B., E.W. Gjesfjeld, W.A. Brown, M.J. Hudson and J.D. Shaw (2016). Resilience and the population history of the Kuril Islands, Northwest Pacific: A study in complex human ecodynamic, Quaternary International, 419, 165-193.

Fitzpatrick, S.M., Thompson V.D., Poteate A.S., Napolitano M.F. and J.M. Erlandson (2016). Marginalization of the Margins: The Importance of Smaller Islands in Human Prehistory, The J. Island Coastal Archaeol., 11:2, 155170.

Gliozzo, E. (2020). Ceramic technology. How to reconstruct the firing process, Archaeol. Anthropol. Sci., 12, 260.

Gurova, M., P. Andreeva, E. Stefanova, A. Aladzhova, and C. Bonsall (2021). Petrographic and geochemical analyses of flint raw materials from Bulgaria: A reliable combination for provenance studies of archaeological flint, Quaternary International, In Press, DOI:10.1016/j.quaint.2021.03.023

Hamon, C. (2008). Functional analysis of stone grinding and polishing tools from the earliest Neolithic of northwestern Europe, J. Archaeological Sci., 35(6), 1502-1520.

Horowitz R., and G. McCall (2019). Lithics in Sedentary Societies: Themes, Methods, and Directions. In Horowitz R. and G. McCall (Eds.), Lithic Technologies in Sedentary Societies. Louisville: University Press of Colorado, 335.

Horsburgh, K.A. and M.D. McCoy (2017). Dispersal, Isolation, and Interaction in the Islands of Polynesia: A Critical Review of Archaeological and Genetic Evidence, Diversity 9, 3, 37.

Hunt, A.M.W. (2016). The Oxford Handbook of Archaeological Ceramic Analysis. Oxford University Press, Oxford (UK), p. 600 (ISBN: 9780199681532).

Kadowaki, S. (2021). Neolithic ground stone typology and technology at Göytepe, Edited by Yoshihiro Nishiaki and Farhad Guliyev, Göytepe Neolithic Excavations in The Middle Kura Valley, Azerbaijan, Archaeopress, 223-260.

Lemonnier, P. (1993). Introduction. In: Lemonnier, P. (Ed.), Technological Choices: transformations in material cultures since the Neolithic. Routledge, London, 1-35.

Levi, S.T., V. Cannavò, D. Brunelli (2019). Atlas of Ceramic Fabrics 2. Italy: Southern Tyrrhenian - Neolithic-Bronze Age, Archaeopress, Oxford.

Lucarini, G. and A. Radini (2020). First direct evidence of wild plant grinding process from the Holocene Sahara: Usewear and plant micro-residue analysis on ground stone tools from the Farafra Oasis, Egypt, Quaternary International, 555, 66-84.

Mannino, G. (1979). Ustica: risultati di esplorazioni archeologiche, Sicilia Archeologica, 12, 41, 7-40.

Mannino, G. (1998). Il Neolitico nel palermitano e la nuova scoperta nell'isola di Ustica, in Quaderno del Museo Archeologico Regionale "Antonino Salinas", 4, 45-80.

Mannino, G. and V. Ailara (2014). Le grotte di Ustica. Centro studi e documentazione isola di Ustica, Palermo.

Mannino, G. and V. Ailara (2016). Carta Archeologica di Ustica, Centro Studi e Documentazione Isola di Ustica, Palermo.

Martinelli, M.C., R.H. Tykot and A. Vianello (2019). Lipari (Aeolian Islands) Obsidian in the Late Neolithic. Artifacts, Supply and Function, Open Archaeology, 5, 46-64.

Mathew, A.J., A.J. Woods and C. Oliver (1991). Spots before your eyes: new comparison charts for visual percentage estimation in archaeological material. In: Middleton, A.P., Freestone, I.C., (eds.) Recent developments in ceramic petrology. British Museum Occasional Paper 81, The British Museum, London, 211-263.

Mohr, M. (2019). Forschungen auf dem Monte Iato 2018, Antike Kunst, 62, 121-134.

McLaughlin, T.R., S. Stoddart and C. Malone (2018). Island risks and the resilience of a prehistoric civilization, World Archaeology, 50, 4, 570-600.

Mentesana, R. and P. Fragnoli (2020). The role of ceramic analyses in shaping our understanding of the cultural landscapes of protohistoric Sicily and the Aeolian islands. Journal of Archaeological Science: Reports, 30, 102205.

Mercuri, A.M. (2014). Genesis and evolution of the cultural landscape in central Mediterranean: the 'where, when and how' through the palynological approach, Landscape Ecology, 29, 1799-1810.

Mercuri, A.M., L. Sadori and C. Blasi (2010). Editorial: Archaeobotany for cultural landscape and human impact reconstructions, Plant Biosystems - An International Journal Dealing with all Aspects of Plant Biology, 144, $4,860-864$

Montana, G. (2020). Ceramic raw materials: how to recognize them and locate the supply basins-mineralogy, petrography. Archaeol. Anthropol. Sci., 12, 175.

Muntoni, I. M., E. Delluniversità, I. Allegretta, R. Terzano and G. Eramo (2021), Chert sources and Early to Middle 


\section{Exploitation Georesources in Piano dei Cardoni}

Neolithic exploitation in the Tavoliere (Northern Apulia, Italy), Quaternary International, In Press, https://doi.org/10.1016/j.quaint.2021.01.016

Neall, V.E. (2006). Volcanic soils. Encyclopedia of Life Support Systems (EOLSS), Land use and land cover VII, 1-24. Plieninger, T., and C. Bieling (Eds.) (2012). Resilience and the Cultural Landscape: Understanding and Managing Change in Human-Shaped Environments. Cambridge: Cambridge University Press.

Quinn, P.S. (2010). Interpreting silent artefacts: petrographic approaches to archaeological ceramics, Archaeopress, Oxford (UK), 297.

Rackham, O. (2012). Island landscapes: Some preliminary questions, J. Marine Island Cultur., 1, 2, 87-90.

Renzulli, A., P. Santi, T. Gambin, and P. Bueno Serrano (2019). Pantelleria Island as a centre of production for the Archaic Phoenician trade in basaltic millstones: New evidence recovered and sampled from a shipwreck off Gozo (Malta) and a terrestrial site at Cádiz (Spain), J. Archaeol. Sci.: Reports, 24, 338-349.

Riede, F., G.L. Barnes, M.D. Elson, G.A. Oetelaar, K.G. Holmberg and P. Sheets (2020). Prospects and pitfalls in integrating volcanology and archaeology: A review, J. Volcanol. Geotherm. Res., 401, 106977.

Romano, R., and C. Sturiale (1971). Carta geologica dell'Isola di Ustica. Istituto internazionale di ricerche vulcanologiche; Istituto Internazionale di vulcanologia, Catania, Italy.

Santi, P., A. Renzulli, and M. Bell III (2015). The volcanic millstones from the archaeological site of Morgantina (Sicily): provenance and evolution of the milling techniques in the Mediterranean area, Archaeometry, 57, 5, 803-821.

Sauer, C.O. (1925). The morphology of landscape, Univ. Calif. Publ. Geogr., 2, 2, 19-53.

Spatafora, F. (2009). Ustica tra il Tirreno e la Sicilia. Storia del popolamento dell'isola dalla Preistoria all'età tardoromana. In Ampolo, C. (Ed.), Immagine e immagini della Sicilia e di altre isole del Mediterraneo antico. Vol. I, Scuola Normale Superiore Pisa, Pisa.

Spatafora, F. (2016). Tra mare e terra: la preistoria di Ustica e il Villaggio dei Faraglioni, in Cazzella, A., A., Guidi, and F., Nomi (eds.), Ubi minor... Le isole minori del Mediterraneo centrale dal Neolitico ai primi contatti coloniali, Scienze dell'Antichità, 22, 2, 315-326.

Shackleton, N., and N.D. Opdyke (1973). Oxygen isotope and palaeomagnetic stratigraphy of Euquatorial Pacific core V28-238: oxygen isotope temperatures and ice volumes on a 10' year and 10' year scale, Quaternary Res. 3, 1, 39-55.

Speciale, C., N. Larosa, G. Battaglia and S. Vassallo (2019). Piano dei Cardoni, Ustica (Palermo), Notiziario Istituto di Preistoria e Protostoria, 6.2, 62-64.

Speciale C., K. Freund, V. Forgia, S. de Vita, N. Larosa, G. Battaglia, R.H. Tykot and S. Vassallo (2021a). Obsidian from the Site of Piano dei Cardoni, Ustica (Palermo, Italy): Preliminary Results on the First Occupation of the Island, Open Archaeology, 7, 1, 273-290.

Speciale, C., N. Larosa, F. Spatafora, A.M.G. Calascibetta, G.P. Di Sansebastiano, G. Battaglia and S. Pasta (2021b). Archaeobotanical and historical insights on some steps of forest cover disruption at Ustica Island (Sicily, Italy) from prehistory until present day, Environ. Archaeol., doi:10.1080/14614103.2021.1962578.

Speciale, C., N. Larosa, A. Magrì and G. Battaglia, Piano dei Cardoni, Ustica (Palermo), Notiziario Istituto di Preistoria e Protostoria, submitted.

Van der Geest, H., J. Vellekoop, P. Kaskes, M. Sinnesael, J. Jagt, P. Degryse and P. Claeys (2021). Petrographic and geochemical fingerprinting of flints from the type-Maastrichtian (SE Netherlands and NE Belgium): implications for flint formation and provenance, EGU General Assembly 2021, online, 19-30 Apr 2021, EGU212335.

Walter, R.K. and R.J. Hamilton (2014). A cultural landscape approach to community-based conservation in Solomon Islands, Ecology and Society 19, 4, 41.

Whitbread, I.K. (1995). Greek transport amphorae: a petrological and archaeological study. London: British School at Athens.

Williams, J.Ll. (1980). A Petrological Examination of The Prehistoric Pottery from the Excavations in the Castello and Diana Plain of Lipari. In Bernabò Brea, L. and M., Cavalier. (Eds), Meligunìs Lipára, IV. L’acropoli di Lipari nella preistoria. Palermo, 847-868.

Williams, J.Ll. and S.T. Levi (2008). The Ausonian Pottery of Lipari (Aeolian Islands, Sicily) - a Typological and Petrological assessment, PPS 74, 141-170. 


\section{Claudia Speciale et al.}

*CORRESPONDING AUTHOR: Claudia SPECIALE

Istituto Nazionale di Geofisica e Vulcanologia, Osservatorio Vesuviano, Naples, Italy and Departiment of Historical studies, University of Gothenburg, Sweden; e-mail: claudiaspciale@gmail.com (c) 2021 the Author(s). All rights reserved. Open Access. This article is licensed under a Creative Commons Attribution 3.0 International 